\title{
$B R C A 1$ and $B R C A 2$ mutation status and cancer family history of Danish women affected with multifocal or bilateral breast cancer at a young age
}

\author{
J T Bergthorsson, B Ejlertsen, J H Olsen, A Borg, K V Nielsen, R B Barkardottir, \\ S Klausen, H T Mouridsen, K Winther, K Fenger, A Niebuhr, T L Harboe, E Niebuhr
}

Department of Medical Genetics, Institute for Medical Biochemistry and Genetics, Panum Institute, Blegdamsvej 3, 2200 Copenhagen $N$, Denmark

J T Bergthorsson

K V Nielsen

$\mathrm{K}$ Winther

K Fenger

A Niebuhr

T L Harboe

E Niebuhr

Laboratory of Cell Biology, Department of Pathology,

University Hospital of Iceland, Landspitalinn, Building 14, 101 Reykjavik, Iceland J T Bergthorsson R B Barkardottir

Department of Oncology, The Finsen Centre, Rigshospitalet, Building 5-01-2, Blegdamsvej 9, 2100

Copenhagen, Denmark B Ejlertsen

H T Mouridsen

Division for Cancer Epidemiology, Danish Cancer Society,

Strandboulevarden 49, 2100 Copenhagen,

Denmark

J H Olsen

Department of Oncology, University Hospital, S-221 85

Lund, Sweden

A Borg

Department of Anatomy and Pathology, Herlev University Hospital, Herlev Ringvej, 2730 Herlev, Denmark

S Klausen

Correspondence to: Dr Bergthorsson, Iceland, nonni@rsp.is

Revised version received 26 March 2001

Accepted for publication 27 March 2001

\section{Abstract}

Introduction-A small fraction of breast cancer is the result of germline mutations in the $B R C A 1$ and $B R C A 2$ cancer susceptibility genes. Mutation carriers frequently have a positive family history of breast and ovarian cancer, are often diagnosed at a young age, and may have a higher incidence of double or multiple primary breast tumours than breast cancer patients in general.

Objectives-To estimate the prevalence and spectrum of $B R C A 1$ and $B R C A 2$ mutations in young Danish patients affected with bilateral or multifocal breast cancer and to determine the relationship of mutation status to family history of cancer.

Subjects-From the files of the Danish Breast Cancer Cooperative Group (DBCG), we selected 119 breast cancer patients diagnosed before the age of 46 years with either bilateral $(n=59)$ or multifocal $(n=61)$ disease.

Methods-DNA from the subjects was screened for $B R C A 1$ and $B R C A 2$ mutations using single strand conformation analysis (SSCA) and the protein truncation test (PTT). Observed and expected cancer incidence in first degree relatives of the patients was estimated using data from the Danish Cancer Registry.

Results-Twenty four mutation carriers were identified $(20 \%)$, of whom 13 had a $B R C A 1$ mutation and 11 carried a $B R C A 2$ mutation. Two mutations in $B R C A 1$ were found repeatedly in the material and accounted for seven of the $24(29 \%)$ mutation carriers. The mutation frequency was about equal in patients with bilateral $(22 \%)$ and multifocal breast cancer $(18 \%)$. The incidence of breast and ovarian cancer was greatly increased in first degree relatives of $B R C A 1$ and $B R C A 2$ mutation carriers, but to a much lesser degree in relatives of non-carriers. An increased risk of cancer was also noted in brothers of non-carriers.

Conclusions-A relatively broad spectrum of germline mutations was observed in $B R C A 1$ and $B R C A 2$ and most of the mutations are present in other populations. Our results indicate that a diagnosis of bilateral and multifocal breast cancer is predictive of $B R C A 1$ and $B R C A 2$ mutation status, particularly when combined with information on the patients' age at diag- nosis and family history of breast/ovarian cancer.

(F Med Genet 2001;38:361-368)

Keywords: breast cancer; mutations; $B R C A 1 ; B R C A 2$

Hereditary breast and ovarian cancer (HBOC) syndrome is characterised by familial clustering of breast cancer diagnosed at an early age and increased incidence of ovarian cancer. Mutations in two cancer susceptibility genes, $B R C A 1$ and $B R C A 2$, seem to be responsible for the majority of breast cancers associated with the HBOC syndrome and these genes may also account for a small $(\sim 5 \%)$ but significant fraction of the total breast cancer incidence in western countries. ${ }^{1}$

Since the cloning of $B R C A 1$ and $B R C A 2$ in 1995 and $1996,{ }^{2}{ }^{3}$ several functional studies have been published. The BRCA1 and BRCA2 proteins are involved in regulation of gene transcription and DNA repair that is based on homologous recombination. Disruption of their normal function probably results in inability to repair chromosome breakage, which may lead to cancer when accumulation of such aberrations occurs in genes that control proliferation and/or differentiation. ${ }^{4}$ Although the basic function of the proteins may overlap and both genes interact with the RAD51 protein, which is essential for recombination based DNA repair, mutations in the two genes have to some degree been associated with a distinct phenotype. For example, the profiles of somatic chromosome changes appear to be distinct in $B R C A 1$ and $B R C A 2$ defective tumours. ${ }^{5}$ The cancer spectrum is also slightly different in BRCA1 and BRCA2 linked families; for example, ovarian cancer is reported to be more common in BRCA1 mutation carriers while $B R C A 2$ mutations are associated with increased risk of male breast cancer and cancer of the pancreas..$^{6-8}$ The pathology associated with mutations in the two genes also appears to differ. ${ }^{9}$ There is also some evidence for heterogeneity in the expression of both $B R C A 1$ and $B R C A 2$ mutations, which may be caused by additional genetic or environmental factors and allelic variation. ${ }^{10-12}$ Studies of high risk families indicate that the penetrance associated with positive $B R C A 1$ and $B R C A 2$ mutation status is high, or close to $90 \%$ in terms of lifetime risk. ${ }^{6}$ Lower estimates of the penetrance have been obtained from studies of cancer incidence in first degree relatives of mutation carriers who have been identified without previous consideration of their family history. ${ }^{13}{ }^{14}$ 
Multiple primary cancer is well established as a consequence of inherited cancer syndromes. In HBOC families, a high incidence of bilateral breast cancer and the occurrence of breast and ovarian cancer in the same subject have been noted. ${ }^{15}$ The clinical and biological significance of multiple ipsilateral tumour lesions remains an unsolved puzzle. Bilateral and ipsilateral multiplicity have features in common and are associated with one another. ${ }^{16}$ Macroscopically distinct tumour lesions may result from intramammary tumour spread as well as growth of independent primary tumours. Bilateral breast cancers are frequently noted in BRCA1 and BRCA2 families, but the relationship of ipsilateral multiplicity to $B R C A 1$ and $B R C A 2$ mutation status is unknown.

The purpose of this study was to describe the mutation spectrum in the $B R C A 1$ and $B R C A 2$ genes in the Danish population and to determine the proportion of founder mutations. The association of positive mutation status with multiple breast cancer was also assessed by selecting consecutive series of young patients with either bilateral or multifocal breast cancer and this criterion was then further evaluated in conjunction with information on the patients' family history of cancer.

\section{Material and methods}

SUBJECTS

Nationwide guidelines for surgery, pathology, radiotherapy, systemic therapy, and follow up were agreed upon by virtually all Danish departments involved in the foundation of the Danish Breast Cancer Cooperative Group (DBCG) in 1977. Major revisions of the guidelines have been ratified in 1982, 1989, and 1998. The DBCG registry comprises all women with primary breast cancer and all diagnostic, therapeutic, and follow up data are reported to the registry using standardised forms.

Patients diagnosed with breast cancer before the age of 46 years and affected with either bilateral breast cancer or more than one ipsilateral and macroscopically distinct tumour lesion (multifocal breast cancer) were identified via the DBCG registry. From the patients with bilateral breast cancer, 58 tumour samples were obtained from the DBCG tissue bank. A sample of nearly equal size (61 patients) was then obtained from patients diagnosed with multifocal breast cancer. The median age at onset of breast cancer for these 119 patients was 39 years (range 24-45 years). Bilateral breast cancer was defined as synchronous if bilaterality was diagnosed simultaneously or less than 12 months apart $(n=12)$, and as metachronous if bilaterality occurred 12 or more months apart $(n=46)$.

All patients are identified in the DBCG registry by their full name and their unique personal identification number. This number, assigned to all citizens in Denmark alive on 1 April 1968, incorporates sex and date of birth and permits accurate linkage of information between registries. For patients born after that date, the personal identification number was assigned at birth.

A total of 180 control DNA samples from healthy subjects that we used to compare allele frequencies were kindly provided by Cand Scient Hans Eiberg (Copenhagen family bank).

DNA AND RNA EXTRACTION

Most of the tumour samples were derived from tissue processed for hormone receptor analysis (frozen nuclear pellets or tissue homogenate) and some were obtained as fresh frozen tissue. DNA was extracted using a salting out procedure with reagents provided with the Wiz kit (Promega). Total RNA was isolated using QuickPrep Total RNA extraction kit (Pharmacia Biotech) and the manufacturer's protocol.

MUTATION ANALYSIS

All samples were subjected to mutation analysis by SSCA and PTT. In addition, the control samples were screened by SSCA for variants encoding missense changes that were suspected to be pathogenic.

SSCA was done for all coding $B R C A 1$ exons with primers originally obtained from Dr Nigel Spurr (ICRF, Clare Hall Laboratories, UK). In the case of BRCA2, SSCA was done for all exons except 10 and 11, which were analysed with PTT. The primers were as previously described. ${ }^{17}$ Thermal cycling was performed in $15 \mu \mathrm{l}$ volumes with $0.2 \mathrm{mmol} / 1 \mathrm{dTTP}, \mathrm{dGTP}$, and dATP, $0.01 \mathrm{mmol} / 1$ "cold" dCTP, and 0.25 $\mu \mathrm{Ci} \alpha-{ }^{32} \mathrm{P}$ dCTP (Amersham), 3 pmol of each primer; 30 ng sample DNA, 0.2 units Dynazyme (Finnzyme Oy), and the buffer provided with the enzyme. Thermal cycling was done in five steps with annealing temperatures of $62^{\circ} \mathrm{C}$ (three cycles), $60^{\circ} \mathrm{C}$ (five cycles), $58^{\circ} \mathrm{C}$ (eight cycles), $55^{\circ} \mathrm{C}\left(12\right.$ cycles), and $53^{\circ} \mathrm{C}(17$ cycles), respectively. The amplified products were diluted $5 \times$ in a formamide loading buffer, denatured at $95^{\circ} \mathrm{C}$ for five minutes, and cooled on ice for 5-10 minutes before loading onto the gel. Then $3 \mu \mathrm{l}$ of the sample was electrophoresed in a $0.5 \times$ MDE gel (FMC Bioproducts) using $0.6 \times \mathrm{TBE}$ running buffer under three different conditions: (1) 18-24 hours at $4-6 \mathrm{~W}$ in a cooling room $\left(4^{\circ} \mathrm{C}\right),(2) 6-8$ hours at $30 \mathrm{~W}$ in a cooling room, and (3) $18-24$ hours at room temperature at $4-5 \mathrm{~W}$ and a gel containing $5 \%$ glycerol. The gels were exposed to $x$ ray film (Hyperfilm MP, Amersham) in a $-80^{\circ} \mathrm{C}$ freezer for $12-24$ hours.

Primers used in PTT for amplification of genomic DNA from $B R C A 1$ (exon 11) and $B R C A 2$ (exons 10 and 11) have been described elsewhere. ${ }^{17}$ Exon 11 of the BRCA1 gene was amplified in three overlapping segments. For $B R C A 2$, a single reaction was needed for exon 10 while exon 11 was screened using four different sets of primers. Thermal cycling was done with the Expand High Fidelity PCR system (Boehringer Mannheim) using the manufacturer's protocol. The PCR product was transcribed and translated using the TnT Quick Coupled Transcription/Translation System (Promega). Typically, a $10 \mu 1$ reaction contained $8 \mu \mathrm{l}$ TnT T7 Quick mastermix, $1.5 \mu \mathrm{l}$ 
PCR product, and $0.5 \mu 1 \mathrm{~S}^{35}$ labelled methionine (in vivo cell labelling grade, Amersham). After incubation at $32^{\circ} \mathrm{C}$ for one hour the protein products were diluted $5 \times$ in protein loading buffer, denatured, and electrophoresed on a $12.5 \%$ SDS-PAGE gel. The gels were dried and exposed to an $x$ ray film for 8-24 hours.

For RT-PCR analysis, cDNA was synthesised from total RNA using ExpandTM reverse transcriptase and amplified with the Expand High Fidelity PCR system using protocol suggested by the manufacturer (Boehringer Mannheim).

All samples displaying aberrant mobility in the SSCA or PTT gels were reamplified and 5 $\mu l$ of the amplified product was treated with a mixture of exonuclease I and shrimp alkaline phosphatase. One $\mu \mathrm{l}$ of this mixture was sequenced using the Thermo Sequenase radiolabelled terminator cycle sequencing kit (Amersham). The products were electrophoresed on a $6 \%$ urea sequencing gel using $0.8 \times$ glycerol tolerant gel $($ GTG) buffer. The gels were fixed and dried before exposure to the $x$ ray film.

IDENTIFICATION OF CANCER IN FIRST DEGREE RELATIVES

By use of the personal identification number, each of the breast cancer patients under study was linked to the files of the Central Population Register. For parents born after 1936 and alive at the date of the start of the Central Population Register on 1 April 1968, information was obtained on full name and personal identification number and on date of death or emigration, if applicable. For parents born before 1936 or who had died before 1 April 1968, such information was searched manually in the files of the "parish registers", that is, the population registers of the localities in which the families had lived at the date of birth of the patient, and the date of death obtained from the Danish mortality files. Sisters and brothers of the 119 breast cancer patients were also located in the files of the Central Population Register by using the personal identification number of the mother, or occasionally from the local parish registers. A total of 192 parents (97 mothers and 95 fathers) and 162 sibs (78 sisters and 84 brothers) were found.

Data on the patients' relatives were linked with the Danish Cancer Registry, using the personal identification numbers or, if they had died before 1 April 1968, their date of birth, date of death, and name. The Cancer Registry, which has been in operation since 1942, collects information on all patients with cancer in Denmark. The period of follow up for the occurrence of cancer among parents and sibs extended from the date of birth of the proband with breast cancer to the date of emigration, date of death, or 1 December 1999. Observed cancers were counted and categorised according to a modified version of the International Classification of Diseases, Seventh Revision (ICD-7).

The protocol was approved by the ethical committees of Copenhagen and Frederiksberg municipalities.
EPIDEMIOLOGICAL ANALYSIS

The expected numbers of cancers among first degree relatives of the breast cancer study group were calculated by multiplying the number of person years at risk for each subgroup of relatives, respectively, by the sex specific cancer incidence rates for the Danish population in five year age groups and calendar periods of observation. Standardised incidence ratios (SIRs), taken as the ratios of the observed to the expected number of cancers, and associated $95 \%$ confidence intervals (CIs) were calculated assuming a Poisson distribution of the observed numbers of cancers. ${ }^{18}$ The Fisher exact test was used to compare the prevalence of positive mutation status between disease classes.

\section{Results}

Among the 119 patients, a total of 49 germline sequence variants were identified in the two genes, including pathogenic mutations $(n=19)$, rare sequence variants $(\mathrm{n}=15)$, and common polymorphisms $(n=15)$. The 19 pathogenic mutations were found in $20 \%$ (24/119) of the patients. The majority of these mutations lead to premature termination of the protein translation. Twelve are frameshift mutations, two are nonsense, and one of the mutations affects a splice site. Only four of the mutations are amino acid changes (missense). Six of the pathogenic mutations had not been reported in the Breast Cancer Information Core database (BIC, http://www.nhgri.nih.gov/Intramural research/Lab_transfer/Bic) by May 2000 and are considered novel.

\section{BRCA1 MUTATIONS}

Thirteen $B R C A 1$ mutation carriers and eight distinct mutations were detected in our assays (table 1A). Five of the mutations result in a truncated protein and three are missense mutations. All these mutations have been submitted previously to the BIC database by others. Two mutations were recurrently found in our material. A frameshift mutation in exon 11, $2594 \mathrm{delC}$, was found in four of the patients and three patients had a nucleotide substitution 5208T $>C$ leading to an amino acid change (C1697R).

The other two missense mutations found in BRCA1 were C61G and A1752P. Position 1697 is in a conserved stretch of 23 amino acids that is identical in the human, canine, and mouse brca1. ${ }^{19}$ The $\arg 1697$ allele was tested in a yeast based assay for loss of C-terminal transactivation activity (Vallon-Christersson et al, submitted). Basically, the assay measures the ability of $B R C A 1 \mathrm{C}$-terminal sequences that are fused with a GAL4 DNA binding domain to activate transcription of a reporter gene. $^{20}$ The BRCA1 construct containing $\arg 1697$ was not able to activate transcription in this system, further supporting the C1697R as a pathogenic mutation. Neither the C1697R variant nor A1752P were found in the control material. The region around position 1752 is quite well conserved, although alanine found in human and dog in this position is replaced by a serine in the mouse. In the yeast assay, the 
Table 1 Information for the BRCA1 and BRCA2 mutation carriers identified in this study. Position of mutation by exon; nucleotide change; type of mutation, ie nonsense, frameshift, splice site, or missense; effect of mutation on the protein sequence; patients' age at diagnosis; type of cancer, ie unilateral multifocal disease or bilateral; presence of cancer in first degree relatives of the probands and types of cancer

\begin{tabular}{|c|c|c|c|c|c|c|}
\hline \multicolumn{6}{|c|}{ Proband } & \multirow{2}{*}{$\begin{array}{l}\text { 1st degree relatives } \\
\text { Family history of cancer (site) }\end{array}$} \\
\hline Exon & Mutation & Type & Effect & Age & Characteristics & \\
\hline \multicolumn{7}{|c|}{ BRCA1 mutations } \\
\hline 5 & $300 \mathrm{~T}>\mathrm{G}$ & Missense & C61G & 36 & Bilateral & Yes (breast) \\
\hline 11 & 2594delC & Frameshift & Stop 845 & 36 & Bilateral & Yes (ovary) \\
\hline 11 & 2594delC & Frameshift & Stop 845 & 41 & Multifocal & No \\
\hline 11 & 2594delC & Frameshift & Stop 845 & 28 & Multifocal & Yes (breast) \\
\hline 11 & 2594delC & Frameshift & Stop 845 & 34 & Bilateral & No \\
\hline 11 & $3519 \mathrm{G}>\mathrm{T}$ & Nonsense & Stop 1134 & 28 & Bilateral & No \\
\hline 11 & 3819del5 & Frameshift & Stop 1242 & 34 & Bilateral & No \\
\hline 11 & 3829delT & Frameshift & Stop 1263 & 39 & Bilateral & Yes (ovary) \\
\hline 18 & $5208 \mathrm{~T}>\mathrm{C}$ & Missense & C1697R & 35 & Multifocal & Yes (breast*, cervix) \\
\hline 18 & $5208 \mathrm{~T}>\mathrm{C}$ & Missense & C1697R & 41 & Bilateral & Yes (breast, nasopharynx, skin) \\
\hline 18 & $5208 \mathrm{~T}>\mathrm{C}$ & Missense & C1697R & 44 & Bilateral & Yes (pancreas) \\
\hline 20 & $5373 \mathrm{G}>\mathrm{C}$ & Missense & A1752P & 41 & Multifocal & Yes (breast) \\
\hline 20 & 5382insC & Frameshift & Stop 1829 & 32 & Bilateral & Yes (ovary`, rectum) \\
\hline \multicolumn{7}{|c|}{$B R C A 2$ mutations } \\
\hline 3 & $373 \mathrm{G}>\mathrm{T}$ & Nonsense & Stop 49 & 36 & Bilateral & No \\
\hline 10 & 2041delA $\dagger$ & Frameshift & Stop 613 & 31 & Multifocal & No \\
\hline 11 & 2678delA $\dagger$ & Frameshift & Stop 824 & 27 & Multifocal & No \\
\hline 11 & 5302insA & Frameshift & Stop 1694 & 43 & Multifocal & No \\
\hline 11 & 6310del5† & Frameshift & Stop 2046 & 33 & Bilateral & Yes (breast, prostate, lung) \\
\hline 11 & 6714del4 & Frameshift & Stop 2165 & 34 & Multifocal & No \\
\hline 15 & $7845+1 \mathrm{G}>\mathrm{A} \dagger$ & Splice site & Splice error & 43 & Multifocal & Yes (stomach) \\
\hline 17 & 8138del5 & Frameshift & Stop 2638 & 39 & Bilateral & Yes (ovary) \\
\hline 18 & $8339 \mathrm{C}>\mathrm{T} \dagger$ & Missense & S2704F & 43 & Multifocal & No \\
\hline 23 & 9243delAT† & Frameshift & Stop 3016 & 30 & Bilateral & No \\
\hline 24 & 9474 ins A & Frameshift & Stop 3110 & 39 & Multifocal & Yes (breast) \\
\hline
\end{tabular}

*Two affected relatives.

†Novel mutations.

pro1752 allele was able to activate transactivation, although in comparison to nonpathogenic (polymorphic) amino acid changes tested this ability was reduced. Two other missense changes have been reported near this position (R1751Q and P1749R) and the site may therefore represent a mutation hotspot. ${ }^{21} 22$ The third missense mutation found in $B R C A 1$, $\mathrm{C} 61 \mathrm{G}$, has been seen previously in many breast cancer families throughout Europe. This mutation affects the critical ring finger motif in $B R C A 1$, which is required for binding to the BAP1 and BARD1 proteins. ${ }^{23}{ }^{24}$

Five $B R C A 1$ variants of unknown significance were found in this study (table 2). The three amino acid changes belonging to this category are all located in non-conserved positions of the BRCA1 protein. One of them, S1040N, has previously been found in healthy controls. ${ }^{25}$ The carrier of another variant,

Table 2 Unknown and rare sequence variants identified in the patient group. Name of variant; gene name; effect of variant on the protein level; number of carriers and their age at first diagnosis of cancer; family history and types of cancers diagnosed in first degree relatives

\begin{tabular}{|c|c|c|c|c|}
\hline \multicolumn{4}{|l|}{ Proband } & \multirow{2}{*}{$\begin{array}{l}\text { 1st degree relatives } \\
\text { Family history of cancer (site) }\end{array}$} \\
\hline Variant & Gene & $\begin{array}{l}\text { Amino acid } \\
\text { change }\end{array}$ & $\begin{array}{l}\text { No of patients } \\
\text { (age) }\end{array}$ & \\
\hline $710 \mathrm{C}>\mathrm{T}$ & $B R C A 1$ & None & $1(42)$ & Yes (bladder, eye) \\
\hline $3238 \mathrm{G}>\mathrm{A}$ & $B R C A 1$ & S1040N & $3(43,44,27)$ & Yes (prostate) \\
\hline $4158 \mathrm{~A}>\mathrm{G}$ & $B R C A 1$ & R1347G & $3(34,44,45)$ & Yes (prostate, melanoma, rectum) \\
\hline $4654 \mathrm{G}>\mathrm{T}$ & $B R C A 1$ & S1512I & $1(39)$ & No \\
\hline $4931 \mathrm{~A}>\mathrm{G}$ & $B R C A 1$ & None & $1(38)$ & Yes (connective tissue) \\
\hline $5396+47$ ins 12 & $B R C A 1$ & None & $2(40,45)$ & No \\
\hline $353 \mathrm{~A}>\mathrm{G}$ & $B R C A 2$ & Y42C & $3(40,37,39)$ & No \\
\hline $1029+56 \mathrm{C}>\mathrm{T}$ & $B R C A 2$ & None & $2(39,43)$ & Yes (oesophagus) \\
\hline $7236-62 A>G$ & $B R C A 2$ & None & $2(42,42)$ & No \\
\hline $7663+53 \mathrm{C}>\mathrm{T}$ & $B R C A 2$ & None & $2(42,35)$ & Yes (prostate) \\
\hline $9079 \mathrm{G}>\mathrm{A}$ & $B R C A 2$ & A2951T & $1(34)$ & Yes (lung, lip) \\
\hline $9485-16 \mathrm{~T}>\mathrm{C}$ & $B R C A 2$ & None & $1(42)$ & No \\
\hline $10204 \mathrm{~A}>\mathrm{T}$ & $B R C A 2$ & K3326X & $1(42)$ & No \\
\hline $10338 \mathrm{G}>\mathrm{A}$ & $B R C A 2$ & None & $3(40,37,39)$ & No \\
\hline $10462 A>G$ & $B R C A 2$ & I3412V & $1(41)$ & No \\
\hline
\end{tabular}

S1512I, also had a mutation in the $B R C A 2$ gene suggesting that this variant may also be a neutral polymorphism. A 12 bp insertion/ duplication in intron 20 (IVS20+47ins 12) was found in two patients in our group but was not present in the healthy control population. This variant has been found previously in Polish breast cancer families and at low frequency in normal Polish controls. ${ }^{26}$ More work is therefore needed to elucidate the connection of this variant to familial predisposition.

Of the $13 B R C A 1$ carriers identified in this study, nine had bilateral breast cancer and four had multifocal disease (table 3). The mean time interval between surgery for the first primary cancer and the second occurrence in the contralateral breast was 53 months, about the same as for non-carriers (46 months). The mean age at first diagnosis was 37 years for subjects positive for $B R C A 1$ mutation, which is two years lower than for non-carriers.

BRCA2 MUTATIONS

Eleven BRCA2 mutations were detected of which six have not been reported before (table 1B). None of the mutations was identified in more than one patient. Ten resulted in a truncated protein including one splice site and one nonsense mutation. Only one missense mutation was considered pathogenic.

The splice site mutation occurs in the invariant position of the donor site in intron 15 $(7845+1 \mathrm{G}>\mathrm{A})$. Tumour RNA was available from the patient so the effect of this mutation could be assessed. RT-PCR of a segment containing exons 14-18 gave a band of $900 \mathrm{bp}$ in this sample and the normal sized band of $1050 \mathrm{bp}$ was missing. Sequencing of the aberrant band indicated the absence of exon 15 . The only missense change in BRCA2 
Table 3 Patient classification according to mutation carrier status and type of breast cancer

\begin{tabular}{lrcc}
\hline Mutation carrier status & $\begin{array}{l}\text { Multifocal } \\
\text { unilateral }\end{array}$ & $\begin{array}{l}\text { Synchronous } \\
\text { bilateral }\end{array}$ & $\begin{array}{l}\text { Metachronous } \\
\text { bilateral }\end{array}$ \\
\hline Non-carriers & $50(53 \%)$ & $8(6 \%)$ & $37(41 \%)$ \\
BRCA1 mutation positive & $4(31 \%)$ & $1(8 \%)$ & $8(61 \%)$ \\
BRCA2 mutation positive & $7(64 \%)$ & $3(27 \%)$ & $1(9 \%)$ \\
Total & $61(51 \%)$ & $12(10 \%)$ & $46(39 \%)$ \\
\hline
\end{tabular}

Table 4 Observed number of malignant neoplasms in first degree relatives of the patients (Obs) and standardised incidence ratios (SIR) classified by cancer type and mutation status

\begin{tabular}{|c|c|c|c|c|c|c|c|}
\hline \multirow[b]{2}{*}{ Mutation status } & \multirow{2}{*}{$\begin{array}{l}\text { No of } \\
\text { relatives }\end{array}$} & \multicolumn{2}{|c|}{ All cancers } & \multicolumn{2}{|c|}{$\begin{array}{l}\text { Breast or ovary } \\
\text { cancer }\end{array}$} & \multicolumn{2}{|c|}{ Other cancers } \\
\hline & & Obs & SIR & Obs & SIR & Obs & SIR \\
\hline \multicolumn{8}{|l|}{ All categories } \\
\hline Mothers & 97 & 35 & 1.4 & 20 & $2.9^{\star}$ & 15 & 0.8 \\
\hline Fathers & 95 & 26 & 1.0 & 0 & 0.0 & 26 & 1.0 \\
\hline Sisters & 78 & 11 & $2.3^{\star}$ & 7 & $4.3^{\star}$ & 4 & 1.3 \\
\hline Brothers & 84 & 11 & $3.3^{\star}$ & 0 & 0.0 & 11 & $3.2^{\star}$ \\
\hline All relatives & 566 & $85 \dagger$ & $1.4^{\star}$ & 27 & $3.1^{\star}$ & 58 & 1.1 \\
\hline \multicolumn{8}{|l|}{$B R C A 1$ carriers } \\
\hline Mothers & 12 & 10 & $3.9^{\star}$ & 7 & $10.3^{\star}$ & 3 & 1.6 \\
\hline Fathers & 12 & 3 & 1.0 & 0 & 0.0 & 3 & 1.0 \\
\hline Sisters & 11 & 4 & $8.4^{\star}$ & 3 & $18.1^{\star}$ & 1 & 3.2 \\
\hline Brothers & 14 & 0 & 0.0 & 0 & 0.0 & 0 & 0.0 \\
\hline All relatives & 75 & 17 & $2.5^{\star}$ & 10 & $11.6^{\star}$ & 7 & 1.2 \\
\hline \multicolumn{8}{|l|}{$B R C A 2$ carriers } \\
\hline Mothers & 10 & 3 & 1.4 & 3 & $4.9^{\star}$ & 0 & 0.0 \\
\hline Fathers & 10 & 2 & 0.8 & 0 & 0.0 & 2 & 0.8 \\
\hline Sisters & 8 & 1 & 3.1 & 1 & 9.7 & 0 & 0.0 \\
\hline Brothers & 5 & 1 & 4.7 & 0 & 0.0 & 1 & 4.7 \\
\hline All relatives & 51 & 7 & 1.3 & 4 & $5.5^{\star}$ & 3 & 0.7 \\
\hline \multicolumn{8}{|c|}{ Unknown variants } \\
\hline Mothers & 10 & 2 & 0.6 & 0 & 0.0 & 2 & 0.8 \\
\hline Fathers & 10 & 3 & 0.9 & 0 & 0.0 & 3 & 0.9 \\
\hline Sisters & 2 & 0 & 0.0 & 0 & 0.0 & 0 & 0.0 \\
\hline Brothers & 9 & 3 & $9.5^{\star}$ & 0 & 0.0 & 3 & $9.5^{\star}$ \\
\hline All relatives & 60 & 8 & 1.1 & 0 & 0.0 & 8 & 1.2 \\
\hline \multicolumn{8}{|c|}{ Wild type genotype } \\
\hline Mothers & 65 & 20 & 1.1 & 10 & $2.1^{\star}$ & 10 & 0.8 \\
\hline Fathers & 63 & 18 & 1.1 & 0 & 0.0 & 18 & 1.1 \\
\hline Sisters & 57 & 6 & 1.6 & 3 & 2.3 & 3 & 1.2 \\
\hline Brothers & 56 & 7 & $3.0^{\star}$ & 0 & 0.0 & 7 & $3.0^{\star}$ \\
\hline All relatives & 380 & $53+$ & 1.3 & 13 & $2.1^{\star}$ & 40 & 1.1 \\
\hline
\end{tabular}

${ }^{\star}$ Statistically significant by $95 \%$ confidence limits.

†Including two affected children. region, as it is upstream of the known polymorphic nonsense change K3326X, which was also found in one patient in this study. ${ }^{28}$

Of the $11 B R C A 2$ mutation carriers identified in the study, seven had multifocal breast cancer (table 3 ). The remaining four bilateral cases had a short relapse free time interval (mean=11 months) and two of them had synchronous disease. The average age at diagnosis was about the same as for the $B R C A 1$ carriers (36 years).

\section{FAMILY HISTORY OF CANCER}

The cancer incidence in first degree relatives of the breast cancer patients included in the study is shown in table 4 . The incidence of all cancers was significantly higher than expected for the combined group and the estimated standardised incidence ratio (SIR) was 1.4. Increased cancer incidence was observed in sisters of the patients (SIR 2.3). This is largely because of excess of breast and ovarian cancer (SIR 4.3). As expected, the occurrence of these cancer types in both sisters and mothers is particularly associated with a positive $B R C A 1$ and $B R C A 2$ mutation status. The SIRs for breast/ovarian cancer in the relatives of $B R C A 1$ and $B R C A 2$ mutation carriers were 11.6 and 5.5, respectively. In addition, breast cancer occurred at younger ages in relatives of mutation carriers and the median age at diagnosis was 43 years (range 33-64) but was 54.5 years for relatives of non-carriers (range 39-81). The corresponding figures for ovarian cancer were 46 (range 41-47) and 51 years (41, 51, and 70 years), respectively. Relatives of patients with the wild type genotype also had a significantly increased risk of breast and ovarian cancer but the incidence was only twofold greater than that expected. Other cancer types make up about $42 \%$ (10 of 24 ) of occurrences in first degree relatives of the $B R C A 1$ and $B R C A 2$ mutation carriers, but the same type of cancer never appeared more than once. There is no incidence of breast or ovarian cancer in relatives of patients with a nucleotide variant of unknown significance, implying that in most cases these variants are benign polymorphisms.

Interestingly, the number of cancers observed in brothers of the patients was higher than expected. This effect appears to be mainly associated with brothers of probands that are negative for $B R C A 1$ and $B R C A 2$ mutations, that is, those carrying unknown variants (SIR 10) or do not have a mutation in either gene (SIR 3.0). Various cancer types were observed in the brothers, including cancer of the lung, urinary bladder, skin, testes, and lymphoma.

\section{Discussion}

Of the 19 distinct $B R C A 1$ and $B R C A 2$ gene mutations identified, six are novel changes and these were all in BRCA2. The majority of mutations have previously been detected outside Denmark, including four mutations dispersed over Europe and North America, seven previously detected in North America, and two previously detected in Europe. Two mutations were found recurrently and account for $29 \%$ of all the carriers identified in the study group. 
The most common mutation, 2594delC in $B R C A 1$, has been found previously in Danish breast cancer families and is one of the most common mutations found in breast cancer families from southern Sweden. ${ }^{17}$ Besides being frequently observed in families from the Nordic countries, 2594delC has also been found recurrently in Wales, ${ }^{29}$ which may reflect migration in the Viking age. The second most common mutation, 5208T $>$ C, which was observed in three patients may have a more recent origin since it has not been detected in breast cancer families outside Denmark. In spite of these two recurrent mutations, it appears that the mutation spectrum in Denmark is quite broad, particularly with respect to $B R C A 2$, which argues against a major influence of genetic isolation in the past. The majority of the subjects in this study come from Sealand, which is the most populated area in Denmark and harbours the capital, Copenhagen. Patients from the north of Jutland are under-represented in this material and, consequently, founder mutations that are important in that area may have been missed.

Twenty four $B R C A 1$ or $B R C A 2$ mutation carriers were identified among 119 breast cancer patients. The observed prevalence of $20 \%$ must, however, be viewed in the context of the screening methods and patient selection criteria used. Since the screening methods used in this study are not fully sensitive, some mutations may have been missed. We used three different conditions for SSCA to maximise the sensitivity, which proved to be important since six of the 49 changes found were detected only by one of the conditions used. Mutations in non-coding regions are beyond the scope of this study, that is, changes in introns or regulatory sequences and large genomic deletions. These may nevertheless constitute a significant proportion of the mutations, for example,
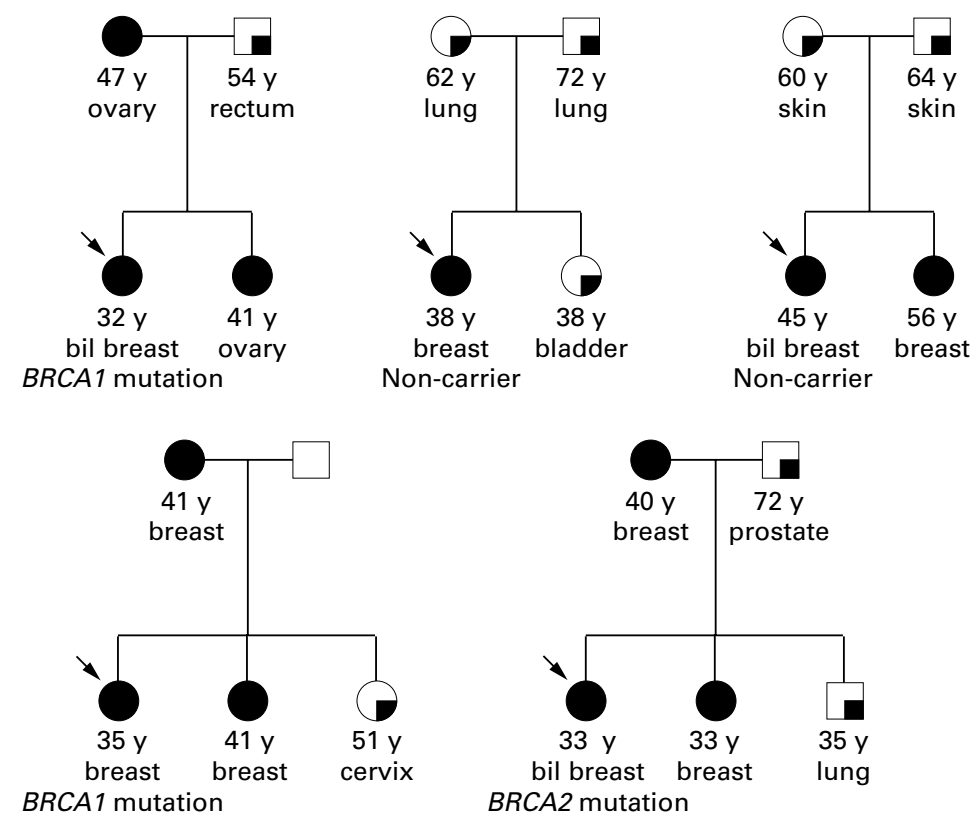

Figure 1 Pedigrees of patients with more than two first degree relatives affected with cancer. The probands are indicated with an arrow. Only affected sibs are shown in the pedigree. Age at diagnosis, site of cancer (bil=bilateral), and mutation status of the probands is given below the symbols. many Dutch breast cancer families are known to segregate large genomic deletions in $B R C A 1 .^{30}$ It is therefore apparent that the mutation frequency given by most screening studies, including our own, are conservative estimates.

The mutation frequency observed here is higher than in most previous studies of consecutive patient series. However, direct comparison with the results of others is rarely meaningful since different patient selection criteria have been used and populations may vary in the frequency of $B R C A 1$ and $B R C A 2$ mutations. Some examples can nevertheless be given; for instance, in one $B R C A 1$ mutation screening study of young American breast cancer patients ( $<45$ years) with an affected first degree relative, 15 carriers were identified in a group of $208(7.2 \%){ }^{31}$ In our study, $36 \%$ of the patients with an affected first degree relative had a mutation in $B R C A 1$. In a British population based study of both $B R C A 1$ and $B R C A 2$, Peto et $a l^{22}$ found a mutation frequency of $5.9 \%$ in patients diagnosed with breast cancer before the age of 36 and $4.1 \%$ in the age range $36-45$ years. The corresponding figures were much higher in this study, 33\% and $16 \%$, respectively. In another study of Ashkenazi Jewish breast cancer patients with bilateral disease, the frequency of $B R C A 1$ and $B R C A 2$ mutations was found to be $82 \%$ in cases with age at onset before 42 years $^{33}$ as compared to $29 \%$ in our material under the same criteria. The broad mutation spectrum observed in this study and the small number of country specific mutations suggests that the mutation frequency does not significantly differ from that observed in other western populations. We therefore suspect that the 4-6 times higher mutation frequency observed in our study as compared with the above mentioned British and American studies is mainly because of the inclusion of multiple cancer in the selection criteria.

As expected, a positive family history of breast or ovarian cancer is more frequent in carriers of $B R C A 1$ or $B R C A 2$ mutations $(50 \%)$ than in those not carrying any mutation (14\%). Nine of 19 first degree relatives with breast cancer and five of eight first degree relatives with ovarian cancer come from a $B R C A 1$ or $B R C A 2$ mutation positive family. In addition, the age at diagnosis of breast and ovarian cancer was approximately 10 years lower in relatives of mutation carriers. Moreover, three of the five pedigrees that have four or more cancer patients include a proband of positive mutation status (fig 1). It is therefore apparent that $B R C A 1$ and $B R C A 2$ explain a large portion of the hereditary component associated with this group of patients. This may either indicate that mutations in other genes that predispose to hereditary breast cancer are rare in the Danish population or that such mutations are less likely to lead to multiple breast cancer. The high prevalence of cancer in brothers of probands who do not carry a mutation in $B R C A 1$ or $B R C A 2$ could signify an additional genetic risk factor (table 4 ). However, the spectrum of cancers observed in the 
brothers implies that the observed increase in risk is non-specific and may result from environmental influences.

The mutation frequency in patients with multifocal tumours $(18 \%)$ is very similar to that in patients with bilateral breast cancer $(22 \%)$. A noticeable difference may have been expected since bilaterality is a well documented feature of $B R C A 1$ and $B R C A 2$ pedigrees and has been associated more strongly with a positive family history of breast cancer. In this study, a family history of breast and ovarian cancer was more common among patients with bilateral disease $(29 \%)$ than those with multifocal disease (12\%). BRCA2 mutations contribute strongly to this effect, since they are more often found in patients with multifocal breast cancer and patients with a negative cancer family history. Of the $B R C A 2$ carriers, $82 \%$ (nine of 11 ) were diagnosed with multifocal or synchronous breast cancer, but only $31 \%$ (four of 13) of the $B R C A 1$ carriers (table 3 ). These differences were not significant by the Fisher's exact test, so whether or not they reflect a stronger predisposition for growth of simultaneous multiple breast tumours in the $B R C A 2$ carriers needs to be evaluated further.

Multifocal breast cancer represents a relatively high fraction of breast cancers in general (30-50\%) in comparison with bilateral breast cancer, which affects only about $5 \%$ of patients. ${ }^{34-36}$ Previous mutation screening studies have not included multifocal disease in the selection criteria, and detailed and prospectively recorded diagnostic information as provided by the DBCG is probably rare. The data presented here therefore add considerably to the data accumulating on the phenotypic consequences of germline mutations in the breast cancer susceptibility genes $B R C A 1$ and $B R C A 2$.

The authors thank Dr Sigurdur Ingvarsson for corrections to this manuscript and Cand Scient Hans Eiberg for providing control DNA samples. This work was supported by a grant to EN from the Danish Research Council (ref 9601797), the Boel Foundation, and the DBCG (Danish Breast Cancer Cooperative Group).

1 Szabo CI, King MC. Population genetics of BRCA1 and BRCA2. Am F Hum Genet 1997;60:1013-20.

2 Miki Y, Swensen J, Shattuck-Eidens D, Futreal PA, Harshman K, Tavtigian S, Liu Q, Cochran C, Bennett LM, Ding W, Bell R, Rosenthal J, Hussey C, Tran T, McClure M, Frye C, Hattier T, Phleps R, Haugen-Strano A, Katcher H, Yakumo K, Gholami Z, Shaffer D, Stone S, Bayer S, H, Yakumo K, Gholami Z, Shaffer D, Stone S, Bayer S, Wray C, Bogden R, Dayananth P, Ward J, Tonin P, Narod S, Bristow PK, Norris FH, Helvering L, Morrison P, Rosteck P, Lai M, Barrett JC, Lewis C, Neuhausen S, Cannon-Albright L, Goldgar D, Wiseman R, Kamb A Skolnick MH. A strong candidate for the breast and ovarSkolnick MH. A strong candidate for the breast and ovarian cance

3 Wooster R, Bignell G, Lancaster J, Swift S, Seal S, Mangion J, Collins N, Gregory S, Gumbs C, Micklem G, Barfoot R, Hamoudi R, Patel S, Rice C, Biggs P, Hashim Y, Smith A, Gudmundsson J, Ford D, Tonin P, Bishop DT, Spurr NK Ponder BA, Eeles R, Peto J, Devilee P, Cornelisse C, Lynch H, Narod S, Lenoir G, Egilsson V, Barkardottir RB, Easton DF, Bentley DR, Futreal PA, Ashworth A, Stratton MR Identification of the breast cancer susceptibility gene BRCA2. Nature 1995;378:789-92.

4 Welcsh PL, Owens KN, King MC. Insights into the functions of BRCA1 and BRCA2. Trends Genet 2000;16: 69-74.

5 Tirkkonen $\mathrm{M}$, Johannsson $\mathrm{O}$, Agnarsson BA, Olsson $\mathrm{H}$, Ingvarsson S, Karhu R, Tanner M, Isola J, Barkardottir RB, Borg A, Kallioniemi OP. Distinct somatic genetic changes Borg A, Kallioniemi OP. Distinct somatic genetic changes
associated with tumor progression in carriers of BRCA1 associated with tumor progression in carriers of BRCA1 and $1222-7$.
6 Ford D, Easton DF, Stratton M, Narod S, Goldgar D, Devilee P, Bishop DT, Weber B, Lenoir G, Chang-Claude J, Sobol H, Teare MD, Struewing J, Arason A, Scherneck S, Peto J, Rebbeck TR, Tonin P, Neuhausen S, Barkardottir R, Eyfjord J, Lynch H, Ponder BA, Gayther SA, Birch JM, Lindblom A, Stoppa-Lyonnet D, Bignon Y, Borg A, Hamann U, Haites N, Scott JR, Maugard CM, Vasen H, Seitz S, Cannon-Albright L, Schofield A, Zelada-Hedman $\mathrm{M}$. Genetic heterogeneity and penetrance analysis of the BRCA1 and BRCA2 genes in breast cancer families. The Breast Cancer Linkage Consortium. Am f Hum Genet 1998;62:676-89.

7 Couch FJ, Farid LM, DeShano ML, Tavtigian SV, Calzone K, Campeau L, Peng Y, Bogden B, Chen Q, Neuhausen S, Shattuck-Eidens D, Godwin AK, Daly M, Radford DM, Sedlacek S, Rommens J, Simard J, Garber J, Merajver S, Weber BL. BRCA2 germline mutations in male breast canWeber BL. BRCA2 germline mutations in male breast cancer cases

8 Goggins M, Schutte M, Lu J, Moskaluk CA, Weinstein CL, Petersen GM, Yeo CJ, Jackson CE, Lynch HT, Hruban RH, Kern SE. Germline BRCA2 gene mutations in patients with apparently sporadic pancreatic carcinomas. Cancer Res 1996;56:5360-4.

9 Breast Cancer Linkage Consortium. Pathology of familial breast cancer: differences between breast cancers in carriers of BRCA1 or BRCA2 mutations and sporadic cases. Lancet 1997;349:1505-10.

10 Phelan CM, Rebbeck TR, Weber BL, Devilee P, Ruttledge MH, Lynch HT, Lenoir GM, Stratton MR, Easton DF, Ponder BA, Cannon-Albright L, Larsson C, Goldgar DE, Ponder BA, Cannon-Albright L, Larsson C, Goldgar DE, Narod SA. Ovarian cancer risk in BRCA1 carriers is modi-
fied by the HRAS1 variable number of tandem repeat fied by the HRAS1 variable number of
(VNTR) locus. Nat Genet 1996;12:309-11

11 Gayther SA, Warren W, Mazoyer S, Russell PA, Harrington PA, Chiano M, Seal S, Hamoudi R, van Rensburg EJ, Dunning AM, Love R, Evans G, Easton D, Clayton D, Stratton MR, Ponder BA. Germline mutations of the BRCA1 gene in breast and ovarian cancer families provide evidence for a genotype-phenotype correlation. Nat Genet 1995;11:42833 .

12 Gayther SA, Mangion J, Russell P, Seal S, Barfoot R, Ponder BA, Stratton MR, Easton D. Variation of risks of breast and ovarian cancer associated with different germline mutations of the BRCA2 gene. Nat Genet 1997;15:103-5.

13 Struewing JP, Hartge P, Wacholder S, Baker SM, Berlin M, McAdams M, Timmerman MM, Brody LC, Tucker MA. The risk of cancer associated with specific mutations of BRCA1 and BRCA2 among Ashkenazi Jews. $N$ Engl f Med 1997;336:1401-8.

14 Thorlacius S, Struewing JP, Hartge P, Olafsdottir GH, Sigvaldason H, Tryggvadottir L, Wacholder S, Tulinius H, Eyfjord JE. Population-based study of risk of breast cancer in carriers of BRCA2 mutation. Lancet 1998;352:1337-9.

15 Olsen JH, Seersholm N, Boice JD Jr, Kruger KS, Fraumeni JF Jr. Cancer risk in close relatives of women with early-onset breast cancer - a population-based incidence study. Br f Cancer 1999;79:673-9.

16 Lesser ML, Rosen PP, Kinne DW. Multicentricity and bilaterality in invasive breast carcinoma. Surgery 1982;91:23440

17 Hakansson S, Johannsson O, Johansson U, Sellberg G, Loman N, Gerdes AM, Holmberg E, Dahl N, Pandis N, Kristoffersson U, Olsson $\mathrm{H}$, Borg A. Moderate frequency of BRCA1 and BRCA2 germ-line mutations in Scandinavian familial breast cancer. Am F Hum Genet 1997;60:1068-78.

18 Rothman KJ, Boice JD. Epidemiologic analysis with a programmable calculator. Washington DC: Government Printing Office, 1979.

19 Szabo CI, Wagner LA, Francisco LV, Roach JC, Argonza R, King MC, Ostrander EA. Human, canine and murine BRCA1 genes: sequence co

20 Monteiro AN, August A, Hanafusa H. Evidence for a transcriptional activation function of BRCA1 C-terminal region. Proc Natl Acad Sci USA 1996;93:13595-9.

21 Friend S, Borresen AL, Brody L, Casey G, Devilee P, Gayther S, Goldgar D, Murphy P, Weber BL, Wiseman R. Breast cancer information on the web. Nat Genet 1995;11: 238-9.

22 Stoppa-Lyonnet D, Laurent-Puig P, Essioux L, Pages S, Ithier G, Ligot L, Fourquet A, Salmon RJ, Clough KB, Pouillart P, Bonaiti-Pellie C, Thomas G. BRCA1 sequence variations in 160 individuals referred to a breast/ovarian family cancer clinic. Institut Curie Breast Cancer Group. Am f Hum Genet 1997;60:1021-30.

23 Jensen DE, Proctor M, Marquis ST, Gardner HP, Ha SI, Chodosh LA, Ishov AM, Tommerup N, Vissing H, Sekido Y, Minna J, Borodovsky A, Schultz DC, Wilkinson KD, Maul GG, Barlev N, Berger SL, Prendergast GC, Rauscher FJ III. BAP1: a novel ubiquitin hydrolase which binds to the BRCA1 RING finger and enhances BRCA1mediated cell growth suppression. Oncogene 1998;16: 1097-112

24 Wu LC, Wang ZW, Tsan JT, Spillman MA, Phung A, Xu XL, Yang MC, Hwang LY, Bowcock AM, Baer R. Identification of a RING protein that can interact in vivo with the BRCA1 gene product. Nat Genet 1996;14:430-40.

25 Durocher F, Shattuck-Eidens D, McClure M, Labrie F, Skolnick MH, Goldgar DE, Simard J. Comparison of BRCA1 polymorphisms, rare sequence variants and/or missense mutations in unaffected and breast/ovarian cancer populations. Hum Mol Genet 1996;5:835-42. 
26 Sobczak K, Kozlowski P, Napierala M, Czarny J, Wozniak M, Kapuscinska M, Losko M, Koziczak M, Jasinska A, Powierska J, Braczkowski R, Breborowicz J, Godlewski D,
Mackiewicz A, Krzyzosiak W. Novel BRCA1 mutations Mackiewicz A, Krzyzosiak W. Novel BRCA1 mutations
and more frequent intron-20 alteration found among and more frequent intron-20 alteration found among 236 wom
$1773-9$.

27 Milner J, Ponder B, Hughes-Davies L, Seltmann M, Kouzarides T. Transcriptional activation functions in BRCA2. Nature 1997;386:772-3.

28 Mazoyer S, Dunning AM, Serova O, Dearden J, Puget N, Healey CS, Gayther SA, Mangion J, Stratton MR, Lynch HT, Goldgar DE, Ponder BA, Lenoir GM. A polymorphic stop codon in BRCA2. Nat Genet 1996;14:253-4.

29 Lancaster JM, Carney ME, Gray J, Myring J, Gumbs C, Sampson J, Wheeler D, France E, Wiseman R, Harper P, Futreal PA. BRCA1 and BRCA2 in breast cancer families from Wales: moderate mutation frequency and two recurrent mutations in BRCA1. Br f Cancer 1998;78:1417-20.

30 Petrij-Bosch A, Peelen T, van Vliet M, van Eijk R, Olmer R, Drusedau M, Hogervorst FB, Hageman S, Arts PJ, Ligtenberg MJ, Meijers-Heijboer H, Klijn JG, Vasen HF, Cornelisse CJ, MJ, Meijers-Heijboer H, Klijn JG, Vasen HF, Cornelisse CJ,
Van't Veer LJ, Bakker E, van Ommen GJ, Devilee P. BRCA1 genomic deletions are major founder mutations in Dutch breast cancer patients. Nat Genet 1997;17:341-5

31 Malone KE, Daling JR, Thompson JD, O'Brien CA, Francisco LV, Ostrander EA. BRCA1 mutations and breast cancer in the general population: analyses in women before age 35 years and in women before age 45 years with first-degree family history. FAMA 1998;279:922-9.

32 Peto J, Collins N, Barfoot R, Seal S, Warren W, Rahman N, Easton DF, Evans C, Deacon J, Stratton MR. Prevalence of BRCA1 and BRCA2 gene mutations in patients with earlyonset breast cancer. F Natl Cancer Inst 1999;91:943-9.

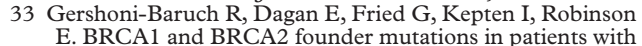
bilateral breast cancer. Eur f Hum Genet 1999;7:833-6.

34 Anastassiades O, Iakovou E, Stavridou N, Gogas J, Karameris A. Multicentricity in breast cancer. A study of 366 cases. Am f Clin Pathol 1993;99:238-43.

35 Westman-Naeser S, Bengtsson E, Eriksson O, Jarkrans T, Nordin B, Stenkvist B. Multifocal breast carcinoma. Am $\mathcal{f}$ Surg 1981;142:255-7.

36 Adami HO, Bergstrom R, Hansen J. Age at first primary as a determinant of the incidence of bilateral breast cancer.
Cumulative and relative risks in a population-based Cumulative and relative risks in a popu
case-control study. Cancer $1985 ; 55: 643-7$.

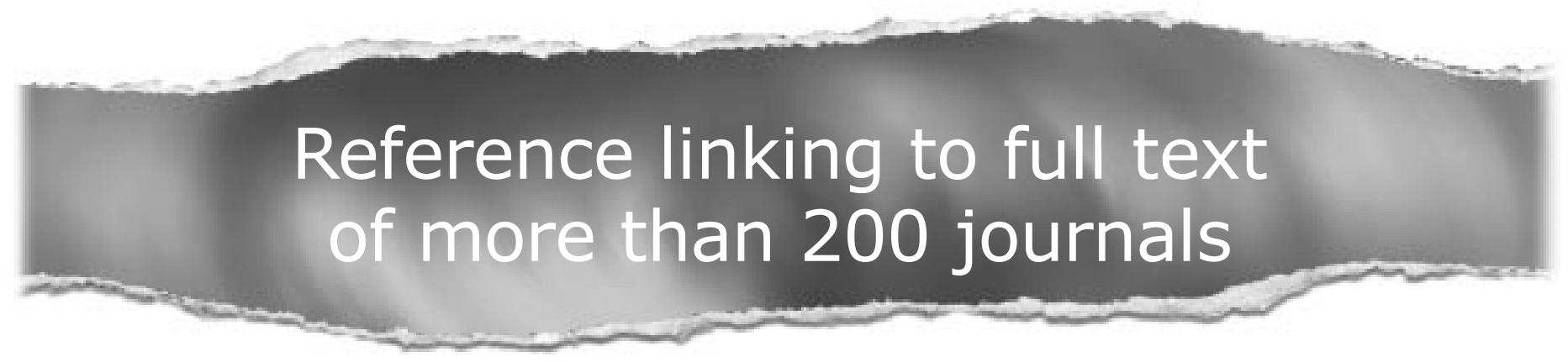

\section{Toll free links}

You can access the FULL TEXT of articles cited in the Journal of Medical Genetics online if the citation is to one of the more than 200 journals hosted by HighWire (http://highwire.stanford.edu) without a subscription to that journal. There are also direct links from references to the Medline abstract for other titles.

www.jmedgenet.com 